\title{
Drug resistance to paclitaxel is not only associated with $A B C B 1$ mRNA expression but also with drug accumulation in intracellular compartments in human lung cancer cell lines
}

\author{
MASANORI SHIMOMURA ${ }^{1,2}$, TAKESHI YAOI $^{2}$, KYOKO ITOH $^{2}$, DAISHIRO KATO $^{1}$, \\ KUNIHIKO TERAUCHI $^{1}$, JUNICHI SHIMADA ${ }^{1}$ and SHINJI FUSHIKI ${ }^{2}$
}

Departments of ${ }^{1}$ General Thoracic Surgery and ${ }^{2}$ Pathology and Applied Neurobiology, Graduate School of Medical Science, Kyoto Prefectural University of Medicine, 465 Kajii-cho, Kawaramachi-Hirokoji, Kamigyo-ku, Kyoto 602-8566, Japan

Received October 9, 2011; Accepted November 18, 2011

DOI: 10.3892/ijo.2011.1297

\begin{abstract}
In order to clarify the mechanisms of resistance to paclitaxel in lung cancer, three human lung cancer cell lines which exhibit different sensitivity to paclitaxel were investigated from the following viewpoints: overexpression of ATP-binding cassette, sub-family $\mathrm{B}$, member $1(A B C B 1)$, mutations on paclitaxel binding site of $\beta$-tubulin genes, quantity of polymerized tubulin and the intracellular localization of paclitaxel. $A B C B I$ expression was evaluated by real-time RT-PCR. No correlations were noted between the $A B C B 1$ expression in the sensitive and resistant cell lines at the mRNA level. No mutations on the paclitaxel binding site of the $\beta$-tubulin genes were detected in either the resistant or sensitive cells. Live cell images obtained by confocal laser microscopy revealed that the resistant cell line, RERF-LC-KJ, had more accumulation of Oregon Green ${ }^{\circledast} 488$ conjugated paclitaxel in the lysosomal and extra-lysosomal compartments of cytoplasm than other cell lines. The results obtained in this study indicated that the changes in the subcellular localization could contribute to the production of paclitaxel resistance in lung cancer cell lines. Further studies should be conducted to elucidate the molecular mechanisms that differentiate the intracellular localization of paclitaxel.
\end{abstract}

\section{Introduction}

Lung cancer is one of the most aggressive cancers and the world's leading cause of cancer mortality. Nevertheless, the treatment of lung cancer still remains unsatisfactory. The 5-year survival rate for lung cancer is reported to be less than $50 \%$ in Japan (1). Paclitaxel is a potent anti-cancer agent that binds to $\beta$-tubulin and prevents mitosis through microtubule over-

Correspondence to: Professor Shinji Fushiki, Department of Pathology and Applied Neurobiology, Graduate School of Medical Science, Kyoto Prefectural University of Medicine, 465 Kajii-cho, Kawaramachi-Hirokoji, Kamigyo-ku, Kyoto, 602-8566, Japan E-mail: sfushiki@koto.kpu-m.ac.jp

Key words: paclitaxel, drug resistance, intracellular localization, lung cancer stabilization. Paclitaxel is known to be effective as a cancer chemotherapeutic agent for ovarian, breast, gastric and lung cancers, but paclitaxel-based chemotherapy for lung cancer is not as effective as it is for other cancer types, with a response rate of $30-40 \%$ (2), since tumor cells develop mechanisms of resistance to the agent.

Several mechanisms have been suggested for this resistance to paclitaxel. The first mechanism reported as a mediator of the resistance to paclitaxel was the overexpression of the multidrug transporter gene, encoding for an efflux pump able to efflux paclitaxel, thereby hampering drug retention. Studies have shown that both the multidrug transporter ATP Binding Cassette, sub-family B, member $1(A B C B 1, M D R 1)(3,4)$ and the ATP Binding Cassette, sub-family $\mathrm{C}$, member $1(A B C C 1, M R P 1)$ (5) play a role in enhancing the cellular efflux of anti-cancer drugs, including paclitaxel. The second mechanism proposed indicated point mutation in the $\beta$-tubulin gene at the paclitaxel binding site as being responsible for the resistance to paclitaxel (6). A correlation was demonstrated between $\beta$-tubulin point mutation and resistance to paclitaxel in lung cancer patients (7). In vitro studies on human cell lines demonstrated that the resistance to paclitaxel resulted from mutations in human class I (M40) $\beta$-tubulin, the predominant isotype, and class IVa $\beta$-tubulin, thereby causing changes in the microtubule dynamics and stability (8-15). Furthermore, altered expression levels of tubulin isotypes have been associated with the development of the resistance to paclitaxel $(6,16)$. Therefore, we addressed the issue of the mechanism of the resistance to paclitaxel by employing three human non-small cell lung cancer cell lines, each of which exhibited a different sensitivity to paclitaxel.

First, we studied the expression of drug transporters and $\beta$-tubulin mutations in the cell lines. However, no correlation was shown between the expression of $A B C B 1$ or $A B C C 1$ and the resistance to paclitaxel, and sequencing of $\beta$-tubulin failed to disclose any mutation in the paclitaxel binding site in any of these cell lines. Therefore, we further investigated the intracellular pharmacokinetics of paclitaxel by measuring the intracellular accumulation of paclitaxel and stabilized tubulin, and by observing live cells treated with fluorescence-labeled paclitaxel. We thus obtained the novel finding that fluorescencelabeled paclitaxel was accumulated more in the lysosomal and 
extra-lysosomal compartments in cells showing a resistance to paclitaxel, compared with other cells.

\section{Materials and methods}

Cell lines and cell cultures. Human lung cancer cell lines II18, PC-14 and RERF-LC-KJ were purchased from RIKEN Cell Bank (Tsukuba, Japan) and RERF-LC-Ad1, A549, RERF-LC-Ad2 and Lu99B were purchased from the Health Science Research Resources Bank (Osaka, Japan). A549 was cultured in Eagle's minimal essential medium (MEM) supplemented with $10 \%$ fetal bovine serum (FBS). The other cell lines were cultured in RPMI-1640 with 10\% FBS. All of the media were supplemented with penicillin-streptomycin sulfate (Nacalai Tesque Inc., Kyoto, Japan). All of the cell lines were incubated in an atmosphere of $95 \%$ air with $5 \% \mathrm{CO}_{2}$ at $37^{\circ} \mathrm{C}$.

Cytotoxicity assay and real-time monitoring of cell proliferation to paclitaxel. Paclitaxel was obtained from Bristol-Myers Squibb (Tokyo, Japan). Drug cytotoxicity for paclitaxel was measured using 2-(2-methoxy-4-nitrophenyl)-3-(4-nitrophenyl)5-(2,4-disulfophenyl)-2H-tetrazolium (WST-8) assays (Dojindo Laboratories, Kumamoto, Japan), according to the manufacturer's protocol. Cells were harvested with trypsin and re-suspended at a final concentration of $2.5 \times 10^{4}$ cells $/ \mathrm{ml}$ for A549 and RERF-LC-KJ, a final concentration of $5.0 \times 10^{4}$ cells $/ \mathrm{ml}$ for RERF-LC-Ad1, RERF-LC-Ad2 and Lu99B, and a final concentration of $1.0 \times 10^{5}$ cells $/ \mathrm{ml}$ for II18 and PC-14, in order to assure appropriate absorbance ranging from 1.0 to 2.0 at $450 \mathrm{~nm}$. Aliquots of each of the suspended cells $(100 \mu \mathrm{l})$ were prepared in triplicate and distributed into 96-well microplates. After incubation for $24 \mathrm{~h}$, the cells were exposed to paclitaxel at various concentrations (ranging from $0.1 \mathrm{nM}$ to $1 \mathrm{mM}$, 8 different concentrations) for $48 \mathrm{~h}$. Subsequently, we then refreshed the medium, followed by adding $10 \mu \mathrm{l}$ WST- 8 to each well and incubation for $2 \mathrm{~h}$ at $37^{\circ} \mathrm{C}$. The absorbance at $450 \mathrm{~nm}$ was determined by a microplate reader (Bio-Rad Laboratories, Tokyo, Japan). The concentrations required to inhibit growth by $50 \%\left(\mathrm{IC}_{50}\right)$ were calculated using KaleidaGraph version 4.0 (Synergy Software, Reading, PA).

The xCELLigence ${ }^{\circledR}$ system (Roche Diagnostics, Tokyo, Japan) was used to quantitatively measure the cell proliferation. Cells $\left(8 \times 10^{4}-1.3 \times 10^{3}\right.$ cells per well) were prepared in triplicate and distributed into E-plate 96 microplates (Roche Diagnostics) to measure the cell index (reflecting the surface area covered by the cells) in each well after $96 \mathrm{~h}$ of incubation. In the cytotoxicity assay, cells were re-suspended at $1 \times 10^{4}$ cells for PC-14, A549 and RERF-LC-Ad2, 2x10 ${ }^{4}$ cells for II18 and Lu99B and $4 \times 10^{4}$ cells for RERF-LC-Ad1 and RERF-LC-KJ, respectively, in order to assure an appropriate cell index. Cells were prepared in triplicate, with $200 \mu \mathrm{l}$ of an appropriate medium with $10 \%$ FBS. After $24 \mathrm{~h}$ of incubation, the cells were exposed to $25 \mu \mathrm{l}$ of paclitaxel at various concentrations. The cells were monitored every $15 \mathrm{~min}$ (up to $48 \mathrm{~h}$ ), followed by monitoring at 1-h intervals (from 48 to $96 \mathrm{~h}$ ). $\mathrm{IC}_{50}$ was calculated using the RTCA-integrated software of the xCELLigence ${ }^{\circledR}$ system.

Total RNA preparation from paclitaxel-exposed cells. We harvested the cells exposed to $3.2 \mathrm{nM}(-8.5 \log \mathrm{M})$ paclitaxel at different time points, at $0,6,12,18,24$ and $48 \mathrm{~h}$ in culture, respectively. The total cellular RNA was isolated from the cells using the RNeasy Mini Kit (Qiagen, Tokyo, Japan). After treatment with RNase-free DNase I (Nippongene, Tokyo, Japan) for $30 \mathrm{~min}$ at $37^{\circ} \mathrm{C}$, the RNA was processed for purification with an RNeasy MinElute Cleanup Kit (Qiagen).

Real-time quantitative RT-PCR. First-strand cDNAs were synthesized with a Superscript VILO ${ }^{\circledR}$ cDNA synthesis kit (Invitrogen, Tokyo, Japan). Real-time quantitative PCR of the target genes was performed with an ABI PR ISM 7000 (Applied Biosystems, Carlsbad, CA) and a SYBR Premix Ex Taq Perfect Real-Time (Takara-Bio, Otsu, Japan). PCR reactions were carried out under the following conditions: $95^{\circ} \mathrm{C}$ for $10 \mathrm{sec}$, followed by 40 cycles of $95^{\circ} \mathrm{C}$ for $5 \mathrm{sec}$ and $65^{\circ} \mathrm{C}$ for $35 \mathrm{sec}$. The PCR primers were designed using Primer 3 Plus software ${ }^{\circledR}$ as follows: $A B C B 1,5$ '-TCCTGGAGCGGTTCTACGAC-3' (sense) and 5'-GCTGCAGTCAAACAGGATGG-3' (antisense);

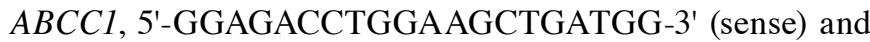
5'-AGGGCTCCATAGACGCTCAG-3' (antisense); GAPDH, 5'-GAAGGTGAAGGTCGGAGTC-3' (sense), 5'-GAAGAT GGTGATGGGATTTC-3' (antisense). The results were normalized to the levels of GAPDH and relative quantification was calculated using the $\triangle \Delta C T$ method (17). Relative mRNA expressions were expressed as fold changes relative to the expression level of the gene on A549 at time zero.

Sequencing of $\beta$-tubulin. The primers employed for the PCR amplification and sequencing of the $\beta$-tubulin isotype are summarized in Table I. The total RNA $(1 \mu \mathrm{g})$ was reversely transcribed to cDNA using a SuperScript ${ }^{\circledR}$ II RNase H-Reverse Transcriptase Kit (Invitrogen). PCR products were synthesized using KOD-plus (Toyobo, Osaka, Japan) according to the manufacturer's protocols, and loaded onto $2 \%$ agarose gel. Following electrophoresis, the appropriate bands were purified using Wizard ${ }^{\circledR}$ SV Gel and PCR Clean-Up System (Promega, Madison, WI) according to the manufacturer's instructions. The products were purified by ethanol precipitation and added to BigDye ${ }^{\circledR}$ Terminator v3.1 Cycle Sequencing Kit (Applied Biosystems) and then processed for sequencing using an Applied Biosystems 3130 Genetic Analyzer (Applied Biosystems). Sequences of the $\beta$-tubulin isotype were aligned using Clustal-W2 (European Bioinformatics Institute) and Boxshade programs.

Paclitaxel accumulation assay. The accumulation of paclitaxel in all of the cells was measured using $\left[{ }^{3} \mathrm{H}\right]$-paclitaxel (Moravec Biochemicals Inc., Brea, CA), employing a modification of the methods previously described $(18,19)$.

First, the cells were quadricated and distributed into 96-well plates at the described cellular count for a cytotoxic assay with $\mathrm{xCELLigence}^{\circledR}$ system. After incubation for $24 \mathrm{~h}$, the cells were exposed to $3.2 \mathrm{nM}(-8.5 \log \mathrm{M})\left[{ }^{3} \mathrm{H}\right]$-paclitaxel for the following $6,12,18,24$ and $48 \mathrm{~h}$. After washing three times with ice-cold phosphate-buffered saline (PBS), the cells were trypsinized, and then triplicated and solubilized with $1 \%$ Triton-X and $0.2 \%$ sodium dodecylsulfate (SDS) in $10 \mathrm{mM}$ PBS (pH 7.4), except for one well, which was employed for cell counting. Each solution was transferred to Optiplate- $96^{\circledast}$ (Perkin-Elmer, Waltham, MA) and added to Microscinti $40^{\circledR}$ (Perkin-Elmer). The radioactivity was measured as counts per min (CPM) using 
Table I. Set of primers for PCR amplification and nucleotide sequencing of $\beta$-tubulin isotype.

\begin{tabular}{llll}
\hline Primer & Sequence for PCR amplification & \multicolumn{1}{c}{ Primer } & Sequence for sequencing reaction \\
\hline $\begin{array}{l}\text { Class I } \\
\text { Forward (88-108) }\end{array}$ & ATACATACCTTGAGGCGAGCA & Forward (687-706) & CTCTCCGTCCATCAGTTGGT \\
Reverse (1488-1507) & GACGGCTAAGGGAACTGAGA & Reverse (1017-1036) & ACAGGCAGCCATCATGTTCT \\
Class II & & & \\
$\begin{array}{l}\text { Forward (83-100) } \\
\text { Reverse (1461-1480) }\end{array}$ & CACCATGCGCGAGATCGT & Forward (702-721) & GCCCTGTATGACATCTGCTT \\
Class III & & Reverse (1052-1070) & CTCGTCCACCTCCTTCATG \\
Forward (65-84) & TATGAGGGAGATCGTGCACA & Forward (644-661) & GGAGAACACGGATGAGAC \\
Reverse (1462-1482) & GGTTTAGACACTGCTGGCTTC & Reverse (944-962) & CATGTTCTTGGCATCGAAC \\
Class IVa & & & \\
Forward (22-39) & TCTCCGCCGCATCTTCCA & Forward (683-703) & GGTGGAGAATACGGATGAGAC \\
Reverse (1472-1492) & ATCAAAGGTCAGAAGCCTCGA & Reverse (983-1004) & CATGTTCTTGGCATCGAACATC \\
Class IVb & & & \\
Forward (50-71) & TCTGCTGCTGTTTGTCTACTTC & Forward (636-654) & AGTGGTGGAGCCCTACAAC \\
Reverse (1461-1480) & GTTCACACTGCTTCCCTGCT & Reverse (985-1005) & AGCCATCATGTTCTTGGCATC \\
\hline
\end{tabular}

a TopCount $\mathrm{NXT}^{\circledR}$ (Perkin-Elmer, Inc.) microplate scintillation and luminescence counter.

Tubulin polymerization assay. Soluble and polymerized tubulins from cell lysates were divided by the following procedures based on a modification of the previously reported method $(6,13,20)$. In brief, cells $\left(1 \times 10^{6}\right.$ cells) exposed to $3.2 \mathrm{nM}$ $(-8.5 \log \mathrm{M})$ paclitaxel for $0,6,12,18,24$ and $48 \mathrm{~h}$ were lysed at $37^{\circ} \mathrm{C}$ with $100 \mu \mathrm{l}$ of hypotonic buffer $[1 \mathrm{mM} \mathrm{MgCl}, 2 \mathrm{mM}$ EGTA, $0.5 \%$ NP-40, a complete mini protease inhibitor cocktail tablet (Roche Diagnostics) and $20 \mathrm{mM}$ Tris- $\mathrm{HCl}$ (pH 6.8)] for $5 \mathrm{~min}$ in the dark. After an additional $100 \mu \mathrm{l}$ of hypotonic buffer was added, the cell lysates were vortexed briefly and sonicated on ice. Following quantification of the protein concentration, the lysate was centrifuged at $14,000 \mathrm{rpm}$ for $10 \mathrm{~min}$ at room temperature. We collected proteins from the supernatant, which contained the soluble tubulin, and the pellet fraction, including polymerized tubulin. Proteins were solubilized in $4 \mathrm{X} \mathrm{NuPAGE}^{\circledR}$ LDS Sample Buffer (Invitrogen) and 10X NuPAGE ${ }^{\circledR}$ Reducing Agent (Invitrogen) and then sonicated on ice. Heat-denatured proteins $(10 \mu \mathrm{l})$ were separated using the NuPAGE ${ }^{\circledR}$ system and NuPAGE ${ }^{\circledR}$ Novex 4-12\% Bis-Tris Gel (Invitrogen), and then transferred onto Hybond-P (GE Healthcare Ltd., Buckinghamshire, UK). SNAP-id (Millipore, Billerica, MA) was used for immunoblotting. A mouse monoclonal anti- $\alpha$ tubulin antibody (1:500) (Sigma-Aldrich, St. Louis, MO) was applied and incubated for $10 \mathrm{~min}$. After the secondary reaction with ECL ${ }^{\circledR}$ peroxidase-labelled anti-mouse NA931VS (1:1000) (GE Healthcare Ltd.) for $10 \mathrm{~min}$, the chemiluminescent signal was visualized by using SuperSignal West pico ${ }^{\circledR}$ (Thermo Fisher Scientific Inc., Waltham, MA) on Versadoc (Bio-Rad Laboratories). We analyzed the protein expression using Quantity One software (Bio-Rad Laboratories).
Measurement of acetylated tubulin. The amount of acetylated tubulin was measured by the modified procedure previously described (14). Proteins were extracted from the total cell lysate using a ProteoExtract ${ }^{\circledR}$ Protein Precipitation Kit (Merck KGaA, Darmstadt, Germany). After transferring the proteins to Hybond-P, the blots were incubated with mouse monoclonal anti-acetylated $\alpha$-tubulin antibody (1:1000) (Abcam, Cambridge, UK) and anti- $\alpha$-tubulin antibody (Sigma-Aldrich), which was used for the tubulin polymerization assay. The secondary reactions and the signal detection were performed similarly to the method described in the section on the tubulin polymerization assay.

Imaging of acetylated tubulin on immunofluorescence microscopy. Seeded on glass coverslips, the cells were exposed to paclitaxel for 6 and $24 \mathrm{~h}$. After the exposure, the cells were fixed with $4 \%$ paraformaldehyde and stained with mouse monoclonal anti-acetylated $\alpha$-tubulin antibody (1:1000). Alexa 488 conjugated goat anti-mouse IgG was used as a secondary antibody. In order to stain $\alpha$-tubulin with the antibody described above, we used Zenon ${ }^{\circledR}$ Mouse IgG Labeling Kits (Molecular probes, Eugene, OR) according to the manufacturer's manual. In order to visualize the nuclei, the cells were stained with 4',6-diamidino-2-phenylindole (DAPI). The immunostained cells were observed and analyzed with a confocal laser microscope LSM 510 (Carl-Zeiss AG, Oberkochen, Germany) and LSM image browser software.

Live cell imaging under confocal laser microscope. All of the cell lines were grown to confluency in culture dishes and trypsinized. Then, $1 \times 10^{4}$ cells were distributed into 4 -well glass-bottom dishes (Matsunami Glass Ind., Inc., Osaka, Japan) coated with poly-L-lysine. After incubation for $24 \mathrm{~h}$, each well 
Table II. Cytotoxicity profile of lung cancer cell lines to paclitaxel.

\begin{tabular}{lcccccccc}
\hline & \multicolumn{7}{c}{ IC $_{50}{ }^{a}$} \\
\cline { 3 - 8 } Exposure time (h) & II18 & RERF-LC-Ad1 & PC-14 & A549 & RERF-LC-Ad2 & Lu99B & RERF-LC-KJ \\
\hline \multirow{2}{*}{ xCELLigence $^{\circledR}$} & 24 & -8.32 & -8.10 & -7.67 & -7.73 & -8.29 & -5.60 & -3.70 \\
& 48 & -8.33 & -7.78 & -7.65 & -7.69 & -8.15 & -5.10 & -4.51 \\
WST-8 $^{\mathrm{b}}$ & 72 & -8.18 & -8.41 & -7.69 & -7.07 & -7.99 & -5.35 & -4.83 \\
& 48 & -10.80 & -9.36 & -9.34 & -8.48 & -7.26 & -7.68 & -4.48 \\
\hline
\end{tabular}

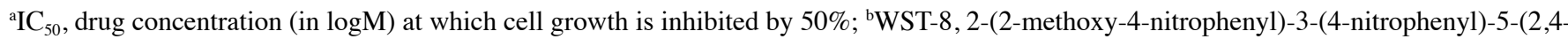
disulfophenyl)-2H-tetrazolium.

was changed to pre-warmed fresh medium containing $100 \mathrm{nM}$ Oregon Green ${ }^{\circledR} 488$ conjugated paclitaxel (Tubulin Tracker $^{\mathrm{TM}}$ ) (Molecular probes) and incubated for 6 and $24 \mathrm{~h}$, with the addition of $100 \mathrm{nM}$ LysoTracker ${ }^{\circledR}$ Red DND-99 (Molecular probes) for $2 \mathrm{~h}$. After the incubation, DAPI was added to the media, followed by incubation for another $30 \mathrm{~min}$. Each dish was washed three times with PBS and observed immediately under the confocal laser microscope LSM 510.

Statistical analysis. The correlation coefficient between the $\mathrm{IC}_{50}$ value shown by the WST- 8 assay and $\mathrm{xCELLigence}{ }^{\circledR}$ system was obtained using simple regression analysis (Excel

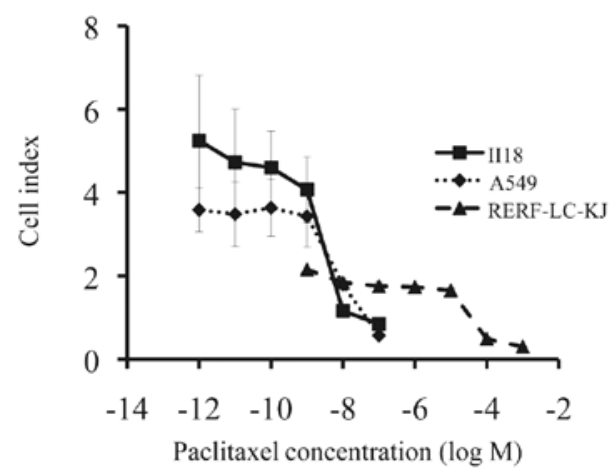

Figure 1 . The effect of paclitaxel varied remarkably between the three lung cancer cell lines. The results of $x$ CELLigence ${ }^{\circledR}$ system were used to measure the cell index, defined as the value reflecting the surface area covered by the living cells. Points, mean of one triplicated experiment; bars, SD. software). In order to determine if the differences in the intracellular accumulation of paclitaxel and gene expressions among the cell lines were statistically significant, the data was analyzed employing one-way analysis of variance, followed by Dunnett's multiple comparisons test.

\section{Results}

Remarkably different resistance to paclitaxel between lung cancer cell lines. In order to study the mechanisms underlying paclitaxel-induced cytotoxicity, we first compared the cellular responses to paclitaxel with two independent assays. Seven lung cancer cell lines from human non-small lung cancers were studied to assess the $\mathrm{IC}_{50}$, and it turned out that their $\mathrm{IC}_{50}$ were widely distributed in the range from -3.70 to $-8.33 \log \mathrm{M}$ and -4.48 to $-10.80 \log \mathrm{M}$, according to the $\mathrm{xCELLigence}{ }^{\circledR}$ system and the WST-8 assay, respectively (Table II). Simple regression analysis showed a strong positive correlation $\left(\mathrm{r}^{2}=0.771\right)$ in both cytotoxicity assays.

RERF-LC-KJ, the most resistant cell line among the cell lines so far examined, was about $10^{4}$ times more resistant to paclitaxel than II18, the most sensitive cell line (Fig. 1). After examining the effect of paclitaxel at calculated $\mathrm{IC}_{50}$ on cellular proliferation with the $\mathrm{xCELLigence}{ }^{\circledR}$ system, we concluded that the cytotoxicity appeared most prominently between 6 and $18 \mathrm{~h}$ after the exposure to paclitaxel, regardless of the cell line (Fig. 2). Thus, we assumed that the most remarkable changes in cellular behavior appeared in the period before $24 \mathrm{~h}$. Because a similar tendency in regard to the resistance to paclitaxel was
II18

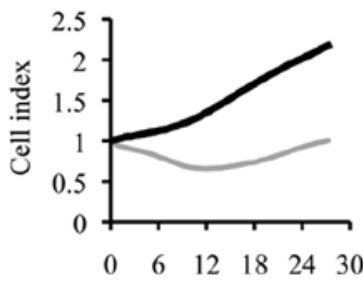

A549

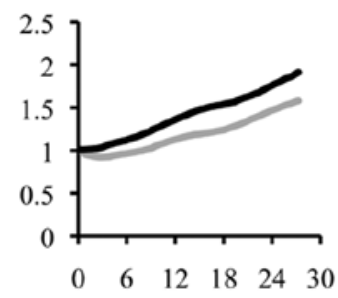

Paclitaxel exposure time (h)
RERF-LC-KJ

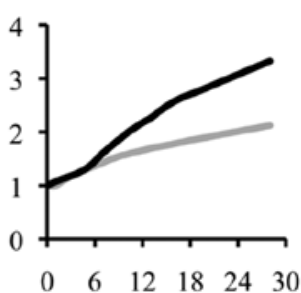

$-\mathrm{IC}_{50}$
- control

Figure 2. The cytotoxicity of paclitaxel under concentrations required to inhibit growth by $50 \%\left(\mathrm{IC}_{50}\right)$ appeared most prominently within $24 \mathrm{~h}$ after the exposure, regardless of the cell line. The cellular proliferation was monitored by xCELLigence ${ }^{\circledR}$ system. After $24 \mathrm{~h}$ of incubation, the cells were exposed to paclitaxel. 


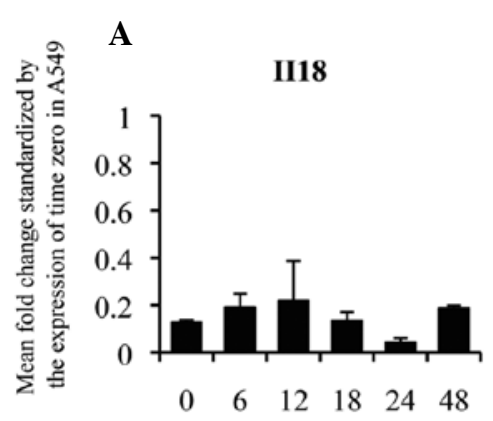

$\mathbf{B}$

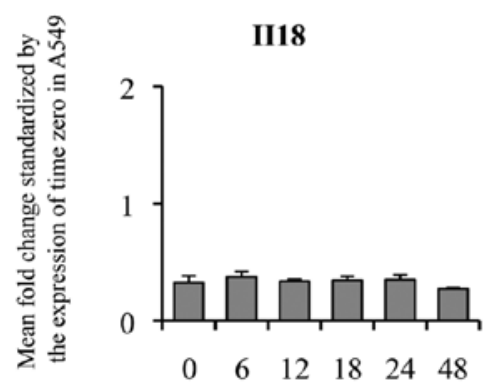

A549

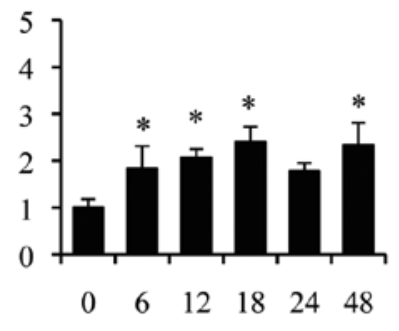

Paclitaxel exposure time (h)

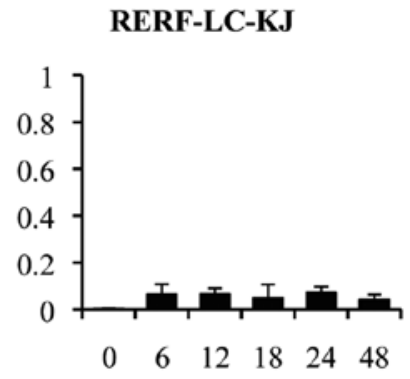

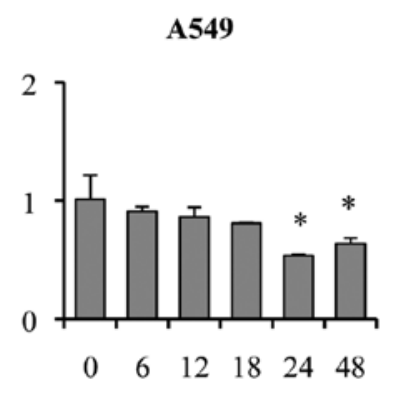

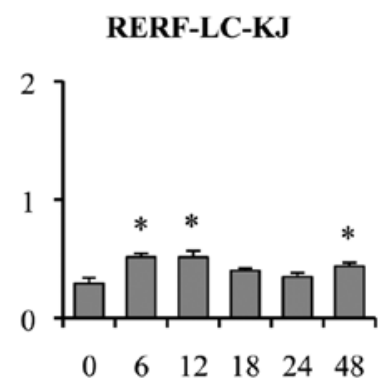

Paclitaxel exposure time (h)

Figure 3. The mRNA levels of $A B C B 1$ (A) changed with time and differed in each lung cancer cell line when exposed to $3.2 \mathrm{nM}$ paclitaxel. The changes in the mRNA level of $A B C C 1$ (B) were modest in the II18 and RERF-LC-KJ cell lines, whereas the expression level significantly decreased at 24 and $48 \mathrm{~h}$ in the A549 cell line. The mRNA levels of $A B C B 1$ and $A B C C 1$ were analyzed by real-time RT-PCR and calculated by the $\triangle \triangle C T$ method. The data are presented relative to the level of $A B C B 1$ and $A B C C 1$ at time zero in the A549 cell line. The expression levels were normalized by the housekeeping gene GAPDH. Columns, the mean of one triplicated experiment; bars, $\mathrm{SD} ;{ }^{*} \mathrm{p}<0.05$ relative to respective untreated $(0 \mathrm{~h})$ cells.

observed with two different assays, we concluded that there was a wide variation in terms of the sensitivity (or resistance) to paclitaxel among the different lung cancer cell lines. We then decided to use three cell lines, i.e., RERF-LC-KJ, A549, and II18 for the following experiments. Taking into consideration the $\mathrm{IC}_{50}$ of the most sensitive cell line II18, we determined the concentration of paclitaxel being as $3.2 \mathrm{nM}(-8.5 \log \mathrm{M})$.

$A B C B 1$ expression level change is not related to resistance to paclitaxel. To further elucidate the relationship between the major drug transporters and the resistance to paclitaxel, we measured the expression of $A B C B 1$ (Fig. 3A) and $A B C C 1$ (Fig. 3B) in lung cancer cell lines by quantitative real-time RT-PCR. A549 showed an elevation of the expression level of $A B C B 1$ between 6 and $12 \mathrm{~h}$. On the other hand, II18 and RERFLC-KJ remained low throughout the experimental period in terms of the expression level of $A B C B 1$.

However, no correlation was shown between the patterns of the expression level of $A B C B 1$ and the resistance to paclitaxel. The expression level of $A B C C 1$ at time 0 for A549 was significantly higher than that of the other cell lines. The ratio of the expression level at time 0 for ABCCl compared to A549 remained in the range from 0.18 to 0.58 , and the changes in the expression level were modest.

Accumulation of $\left[{ }^{3} \mathrm{H}\right]$-paclitaxel corresponded with the expression of $A B C B 1$ in two cell lines. In order to investigate whether the accumulation of paclitaxel was regulated by $A B C B 1$ and $A B C C 1$, and whether the degree of accumulation was correlated to the development of the resistance to paclitaxel, we quantitatively analyzed the time course of the accumulation of intracellular $\left[{ }^{3} \mathrm{H}\right]$-paclitaxel. The accumulation was evaluated as the radioactivity of $\left[{ }^{3} \mathrm{H}\right]$-paclitaxel using CPM divided by the cell count for each well. The accumulation of $\left[{ }^{3} \mathrm{H}\right]$-paclitaxel increased gradually and continuously with time for RERF-LC-KJ, whereas it increased until it reached a peak between 12 or $24 \mathrm{~h}$ and then decreased in the other cell lines (Fig. 4). RERF-LC-KJ showed a low expression of $A B C B I$ throughout the entire time course of the experiment, which corresponded with a higher accumulation of $\left[{ }^{3} \mathrm{H}\right]$-paclitaxel. The correlation coefficient between the expression level of $A B C B 1$ and the accumulation of $\left[{ }^{3} \mathrm{H}\right]$-paclitaxel was -0.804 . On the contrary, the accumulation of $\left[{ }^{3} \mathrm{H}\right]$-paclitaxel in A549 remained low, which correlated well with the high expression level of $A B C B 1$. However, this inverse relationship between the accumulation of $\left[{ }^{3} \mathrm{H}\right]$-paclitaxel and the expression of $A B C B I$ did not apply to the III8 cell line. The correlation coefficient between the expression level of $A B C C l$ and the accumulation of $\left[{ }^{3} \mathrm{H}\right]$-paclitaxel was -0.526 . Thus, we concluded that there was a stronger correlation between the expression of $A B C B 1$ and the intracellular accumulation of paclitaxel compared to that between the expression of $A B C C l$ and the intracellular accumulation of paclitaxel.

Changes in the quantity of polymerized tubulin and acetylated tubulin after exposure to paclitaxel are not related to the resis- 

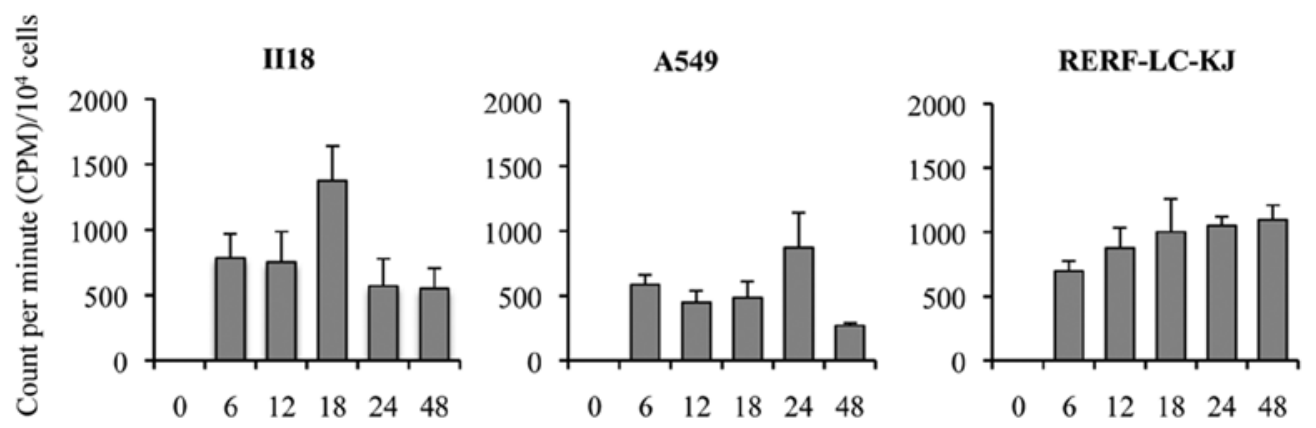

Paclitaxel exposure time (h)

Figure 4. The intracellular accumulation of $3.2 \mathrm{nM}\left[{ }^{3} \mathrm{H}\right]$-paclitaxel increases with time in the RERF-LC-KJ cell line, until it reached a peak between $12-24 \mathrm{~h}$. The values were calculated as the CPM value divided by the cell number of each well. Columns, the mean of one triplicated experiment; bars, SD.

A

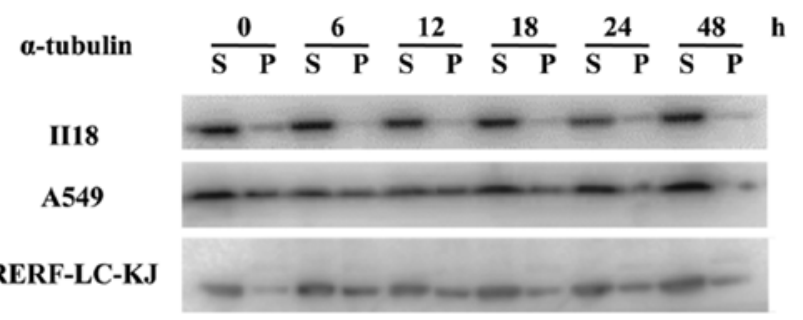

$\mathbf{B}$
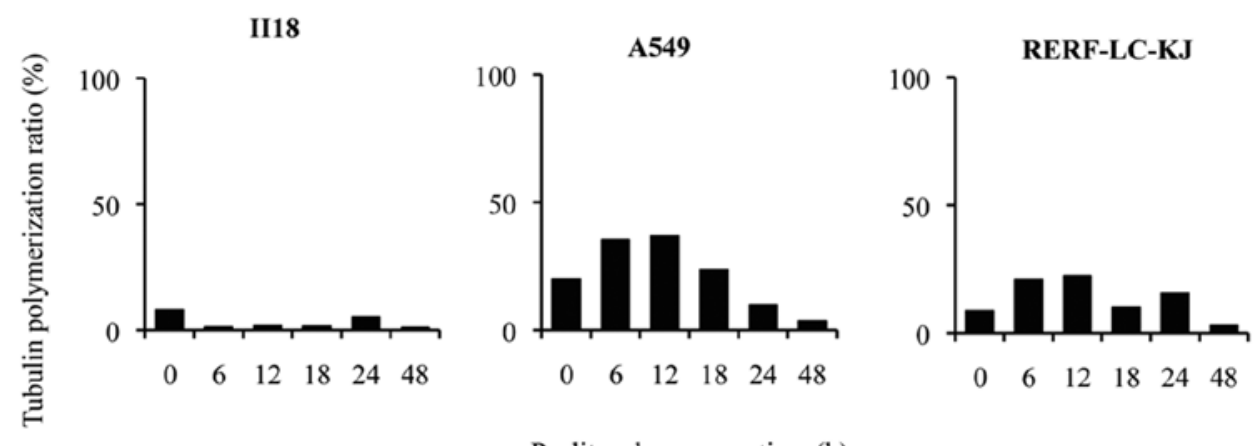

Paclitaxel exposure time (h)

Figure 5. Paclitaxel does not stabilize the microtubules in the II18 cell line for $48 \mathrm{~h}$, whereas it does in the other cell lines, with a peak between 6 or $12 \mathrm{~h}$. (A), Immunoblots of proteins from lung cancer cell lines with antibodies against $\alpha$-tubulin. The loading quantity was equal to $10 \mu \mathrm{g}$ proteins from three $3.3 \mu \mathrm{g}$ total proteins from the cell lines exposed to $3.2 \mathrm{nM}$ paclitaxel. Cells were lysed in hypotonic buffer for $5 \mathrm{~min}$ at $37^{\circ} \mathrm{C}$ followed by separation of the soluble (S) and polymerized (P) fractions by centrifugation. (B), The percentage of polymerized tubulin was obtained by dividing the densitometric value of the polymerized tubulin (insoluble) by the total tubulin contents.

tance to paclitaxel. In the II18 cell line, no correlation was found between the expression level of $A B C B 1$ and the extent of the accumulation of $\left[{ }^{3} \mathrm{H}\right]$-paclitaxel. Therefore, we next performed tubulin polymerization assays to quantify the extent of microtubule stabilization by paclitaxel. The tubulin-polymerized ratio was defined as the percentage of polymerized $\alpha$-tubulin, which was calculated by dividing the densitometric value of polymerized $\alpha$-tubulin (insoluble) by the total $\alpha$-tubulin contents (sum of the densitometric values for soluble and polymerized $\alpha$-tubulin) (Fig. 5). The ratio of polymerized tubulin remained low for $48 \mathrm{~h}$ in the II18 cell line, whereas it increased until a peak value at 6 or $12 \mathrm{~h}$ after the exposure and decreased from 18 to $48 \mathrm{~h}$ in the other two cell lines.

Post-translational acetylation of $\alpha$-tubulin is reported to be associated with the stability of microtubules $(21,22)$. Thus, we evaluated the expression level of acetylated $\alpha$-tubulinemploying the Western blot method (Fig. 6A) and immunocytochemistry (Fig. 6C). The quantification of acetylated $\alpha$-tubulin and $\alpha$-tubulin was performed by the same method employed in the tubulin polymerization assay (Fig. 6B). Images obtained from immunofluorescence staining were also analyzed by measuring the fluorescent intensity at each $1-\mu \mathrm{m}$ deep interval (Fig. 6D). The ratio of the acetylated $\alpha$-tubulin to the total $\alpha$-tubulin remained low for $48 \mathrm{~h}$ in the III 18 cell line, but it increased with time in the RERF-LC-KJ cell line. These analytic results for acetylated $\alpha$-tubulin were consistent with the results obtained in the tubulin polymerization assay.

No paclitaxel binding site mutations in the $\beta$-tubulin isotype were observed in the 3 cell lines. In order to examine whether 
A

II18

$\begin{array}{llllll}0 & 6 & 12 & 18 & 24 & 48\end{array}$

(h)

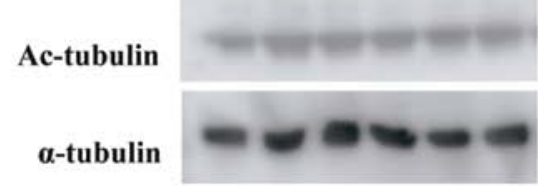

A549

$\begin{array}{lllllll}0 & 6 & 12 & 18 & 24 & 48 & (\mathrm{~h})\end{array}$

Ac-tubulin

a-tubulin

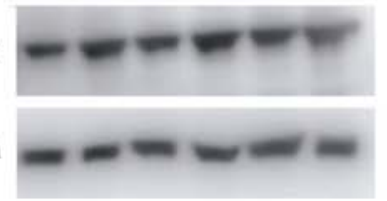

RERF-LC-KJ

$\begin{array}{lllllll}0 & 6 & 12 & 18 & 24 & 48 & (\mathrm{~h})\end{array}$

Ac-tubulin

$\alpha$-tubulin

B

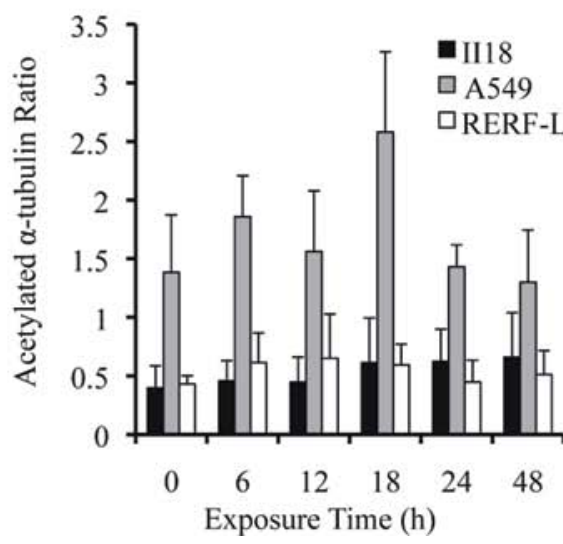

C

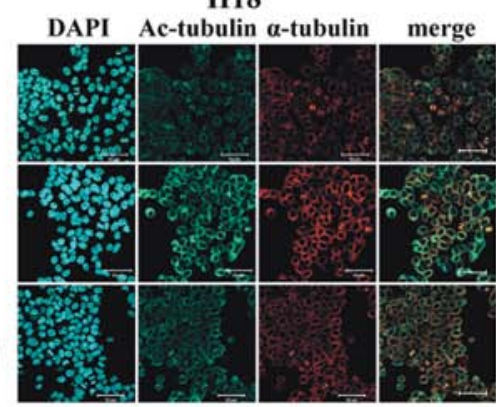

A549

DAPI Ac-tubulin $\alpha$-tubulin merge

0

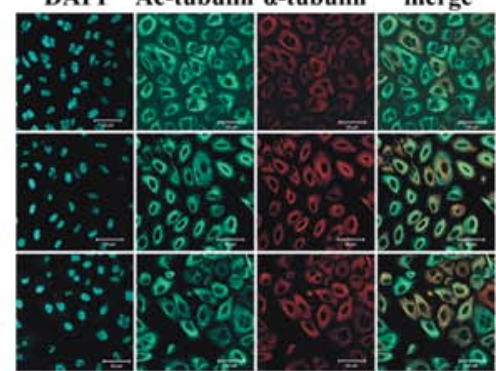

RERF-LC-KJ

DAPI Ac-tubulin $\alpha$-tubulin merge

0

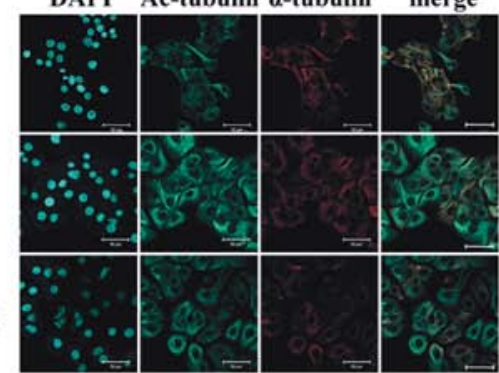

D

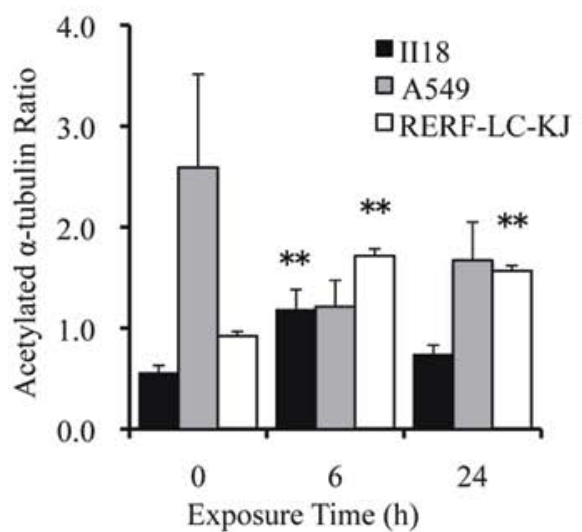

Figure 6. The expression of acetylated $\alpha$-tubulin remained low for $48 \mathrm{~h}$ in the II18 cell line, whereas it increased with time in the RERF-LC-KJ cells. (A), The expressions of acetylated $\alpha$-tubulin and $\alpha$-tubulin were analyzed with the Western blot method using proteins extracted from cells exposed to $3.2 \mathrm{nM}$ (-8.5 $\log \mathrm{M}$ ) paclitaxel for $6,12,18,24$ and $48 \mathrm{~h}$ and untreated $(0 \mathrm{~h})$. (B), The ratio of the expression level of acetylated $\alpha$-tubulin to the total $\alpha$-tubulin was measured. Columns, the mean of value of three experiments; bar, SD. (C), Cellular localization of acetylated microtubules (green) in cells exposed to paclitaxel for 6 and $24 \mathrm{~h}$ and untreated cells. The cells were stained with acetylated $\alpha$-tubulin antibody, microtubules (red) with $\alpha$-tubulin antibody and nuclei (blue) with DAPI. Bar, $50 \mu \mathrm{m}$. (D), The ratio of the expression of acetylated $\alpha$-tubulin to that of $\alpha$-tubulin obtained with immunofluorescent staining was calculated from integrating each fluorescent intensity on a series of stacked images with a thickness of $1 \mu \mathrm{m}$. Columns, mean of value obtained from 3 microscopic fields; bar, SD; ${ }^{* *} \mathrm{p}<0.01$ relative to respective untreated $(0 \mathrm{~h})$ cells.

alterations of the tubulin gene could account for the different levels of drug sensitivity (resistance) to paclitaxel, we sequenced cDNA from the $\beta$-tubulin isotype from the three cell lines. However, no mutations were shown at the paclitaxel binding sites of the $\beta$-tubulin isotypes in any of the cell lines examined (data not shown).
Differences in the intracellular localization of paclitaxel are observed between RERF-LC-KJ and the other cell lines. In order to study the dynamics of the paclitaxel binding to $\beta$-tubulin and microtubules, we performed live cell imaging using Oregon Green ${ }^{\circledast} 488$ conjugated paclitaxel in living cells. As shown in Fig. 7, Oregon Green ${ }^{\circledR} 488$ conjugated paclitaxel 
A

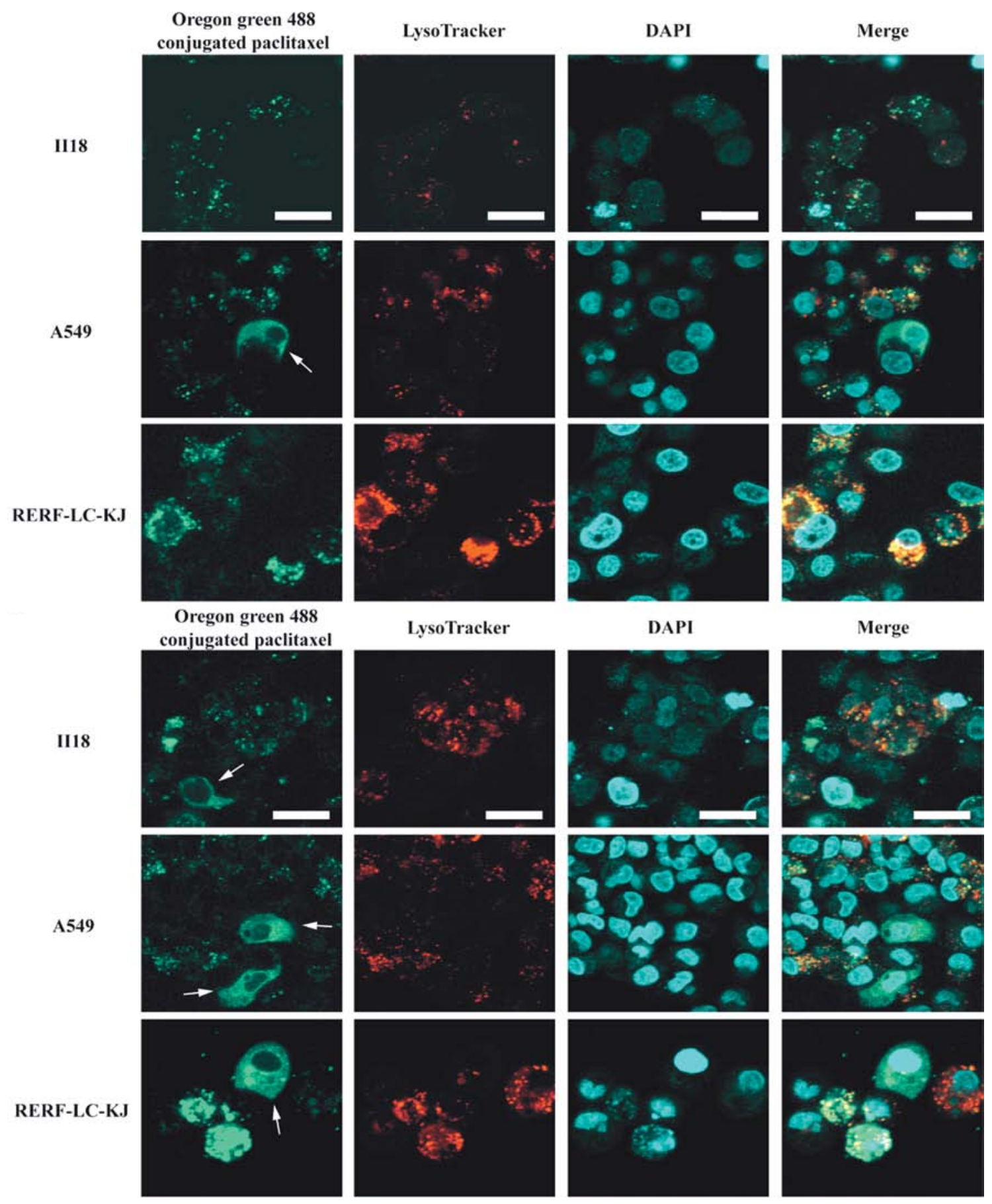

Figure 7. Oregon Green ${ }^{\circledast} 488$-conjugated paclitaxel made it possible to visualize not only the normal microtubules formation, but also the aggregated vesicle formation in some of the RERF-LC-KJ cells, whereas in the other cell lines these vesicular formations were not remarkable. (A and B), Representative confocal images of lung cancer cell lines after the incubation of Oregon Green ${ }^{\circledR} 488$ conjugated paclitaxel for 6 and $24 \mathrm{~h}$, respectively, followed by staining with $100 \mathrm{nM}$ LysoTracker ${ }^{\circledR}$ DND-99 (red) and DAPI (blue). Cellular microtubules are highlighted by white arrows. Bars, $20 \mu \mathrm{m}$.

made it possible to visualize not only the normal microtubule formation on the partial cells, but also the aggregated vesicle formation in some of the RERF-LC-KJ cells, whereas in the other cell lines this phenomenon was not remarkable. Because these vesicular structures did not appear to be composed of microtubules, we conducted tests to determine what cell organelles were associated with these structures, by employing Oregon Green ${ }^{\circledR} 488$ conjugated paclitaxel and LysoTracker ${ }^{\circledR}$ Red. It turned out that colocalization between Oregon Green ${ }^{\circledR} 488$ conjugated paclitaxel with LysoTracker ${ }^{\circledR}$ Red was more frequent in the RERF-LC-KJ cells, compared with the other cell lines. Moreover, in the RERF-LC-KJ cells, Oregon Green ${ }^{\circledR} 488$ conjugated paclitaxel accumulated more in the intracellular compartments, except the lysosomes, compared with the other cell lines.

The pharmacokinetics profile for paclitaxel varies between the cell lines. We summarized the characteristics of the pharmacokinetics for paclitaxel in each cell line from four viewpoints, including the accumulation of paclitaxel, the extent of $A B C B 1$ 
Table III. Profile of mechanisms of the resistance to paclitaxel on each cell line.

\begin{tabular}{lcc}
\hline Cell lines $\quad$ Mechanisms & $\begin{array}{c}\mathrm{IC}_{50} \\
(\log )^{\mathrm{a}}\end{array}$ & $\begin{array}{c}\text { Total summation } \\
\text { of paclitaxel } \\
\text { accumulation }^{\mathrm{b}}\end{array}$ \\
\hline
\end{tabular}

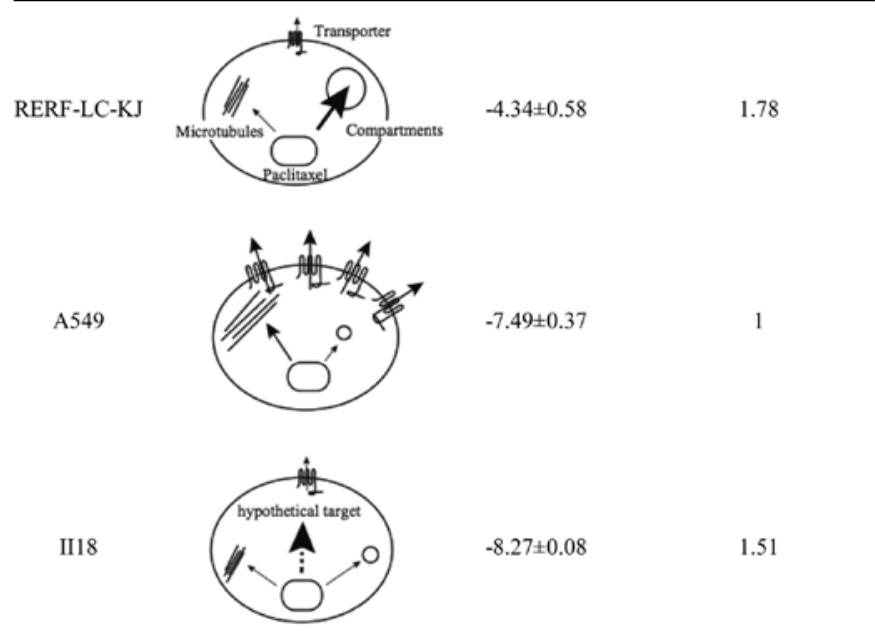

${ }^{\mathrm{a}} \mathrm{IC}_{50}$ was calculated by averaging the data from xCELLigence ${ }^{\circledR}$ system. The values represent means of a triplicate determination \pm $\mathrm{SD} .{ }^{\mathrm{b}}$ This value was obtained from the summation of accumulation value on each time and expressed as fold change compared to A549.

expression, the quantity of the microtubules to which paclitaxel binds, and the volume of paclitaxel which accumulates in the intracellular compartments instead of binding to microtubules. As shown in Table III, A549 exhibited a higher expression level of $A B C B 1$, which resulted in less accumulation of paclitaxel, compared with the other cells. In the RERF-LC-KJ cell line, the expression of $A B C B 1$ was low, and the amount of paclitaxel accumulated intracellularly increased with time. In addition, the rate of tubulin polymerization was maintained at a stable level after the exposure to paclitaxel. The paclitaxel that did not bind to tubulin accumulated preferentially in the intracellular compartments containing lysosomes, in the RERF-LC-KJ cell line. The II18 cell line, the most sensitive to paclitaxel of the cell lines so far examined, showed unique characteristics, since it exhibited lower levels of expression of $A B C B 1$, lower accumulation of paclitaxel, little polymerization of tubulin due to paclitaxel, and little accumulation of paclitaxel in the intracellular compartments.

\section{Discussion}

We demonstrated that a remarkable difference existed in the $\mathrm{IC}_{50}$ values for paclitaxel among the cell lines derived from human non-small cell lung cancers, by using two cytotoxicity assays. Among the cell lines we examined, RERF-LC-KJ exhibited the highest resistance to paclitaxel.

In order to study the underlying mechanism of such high resistance, as seen in RERF-LC-KJ, we studied the time course of the paclitaxel accumulation and the ratio of polymerized tubulin to total tubulin. We found that the cells showed a continuous uptake of paclitaxel with time and an increase in the ratio of polymerized tubulin, with a peak value at $12 \mathrm{~h}$ after the exposure, followed by a gradual decline until $48 \mathrm{~h}$. No mutations were demonstrated in the gene coding for the paclitaxel binding site of the $\beta$-tubulin isotypes. Quantitative RT-PCR did not show any overexpression of $A B C B 1$ or $A B C C 1$. It is noteworthy that the aggregated vesicular structures containing paclitaxel colocalized with lysosomes. Thus, these results might suggest that cells resistant to paclitaxel possess some vesicular compartments including lysosomes for sequestrating paclitaxel, thereby hindering paclitaxel from binding to $\beta$-tubulin.

Lysosomes, one of the intracellular acidic organelles, are known to play critical roles in producing resistance to anticancer drugs, since they trap drugs with weak basic properties in normal cells (23-27), whereas in several cancer cells, the acidification mechanisms of lysosomes were defective, and so the capacity to sequester lysosomotrophic agents was diminished (26). As a result of the low $\mathrm{pH}$ gradient between cytosol and lysosomes, cancer cells have a greater tendency to accumulate drugs in the extra-lysosomal compartments of cells. Paclitaxel, however, is a neutral molecule, because it has no structure to be ionized. Therefore, the $\mathrm{pH}$ gradient between the lysosomes and cytosol does not seem to be associated with the intracellular dynamics of paclitaxel. The nature of the extra-lysosomal compartments accumulating paclitaxel currently remains unknown, but it is tempting to speculate that the structures may possess some drug transporters involved in the efflux or uptake of paclitaxel.

The A549 cell line maintained a higher expression of $A B C B 1$ through $48 \mathrm{~h}$, compared with the other cell lines. Thus, paclitaxel accumulation remained lower in A549, compared with the other cell lines. When we applied the compartment model to the A549 cell line, the cells showed few compartments, so paclitaxel could effectively bind to $\beta$-tubulin. These results were compatible with those seen in reports by Alvarez et al (28), Ambudkar et al (3) and Huang and Sadee (4). On the other hand, it is speculated that there is little association between the expression of $A B C C 1$ and the drug resistance to paclitaxel.

The II18 cell line was the most sensitive to paclitaxel, among the cell lines so far examined. Nevertheless, it accumulated a considerable amount of paclitaxel, with a peak at $18 \mathrm{~h}$ after the exposure and tubulin polymerization proceeded little even at $48 \mathrm{~h}$ after the exposure. We thus conclude that the II18 cell line has a unique feature in terms of its sensitivity to paclitaxel. It would be worth conducting further studies on the intracellular localization of paclitaxel in II18 cells, because it might lead to the identification of a novel molecular target for therapy.

In conclusion, there are multiple underlying mechanisms involved in the development of resistance to paclitaxel, and the predominant factors vary between cell lines. In addition to the mechanisms already proven to be involved with drug resistance, which include drug efflux transporters and mutations of the paclitaxel binding site of $\beta$-tubulin, we hereby propose that a novel mechanism also exists, in which paclitaxel accumulates in some intracellular compartments, which could play an important role in producing resistance to paclitaxel.

\section{References}

1. Sawabata N, Asamura H, Goya T, et al: Japanese Lung Cancer Registry Study: first prospective enrollment of a large number of surgical and nonsurgical cases in 2002. J Thorac Oncol 5: $1369-1375,2010$ 
2. Pujol JL, Barlesi F and Daures JP: Should chemotherapy combinations for advanced non-small cell lung cancer be platinum-based? A meta-analysis of phase III randomized trials. Lung Cancer 51: 335-345, 2006

3. Ambudkar SV, Kimchi-Sarfaty C, Sauna ZE and Gottesman MM: P-glycoprotein: from genomics to mechanism. Oncogene 22: 7468-7485, 2003.

4. Huang Y and Sadee W: Membrane transporters and channels in chemoresistance and sensitivity of tumor cells. Cancer Lett 239: $168-182,2006$.

5. Lee JT Jr, Steelman LS and McCubrey JA: Phosphatidylinositol 3'-kinase activation leads to multidrug resistance protein-1 expression and subsequent chemoresistance in advanced prostate cancer cells. Cancer Res 64: 8397-8404, 2004.

6. Giannakakou P, Sackett DL, Kang YK, et al: Paclitaxel-resistant human ovarian cancer cells have mutant beta-tubulins that exhibit impaired paclitaxel-driven polymerization. J Biol Chem 272: 17118-17125, 1997.

7. Monzó M, Rosell R, Sánchez JJ, et al: Paclitaxel resistance in non-small-cell lung cancer associated with beta-tubulin gene mutations. J Clin Oncol 17: 1786-1793, 1999.

8. Hua XH, Genini D, Gussio R, et al: Biochemical genetic analysis of indanocine resistance in human leukemia. Cancer Res 61: 7248-7254, 2001.

9. Gonzalez-Garay ML, Chang L, Blade K, Menick DR and Cabral F: A beta-tubulin leucine cluster involved in microtubule assembly and paclitaxel resistance. J Biol Chem 274: 23875-23882, 1999 .

10. McGrogan BT, Gilmartin B, Carney DN and McCann A: Taxanes, microtubules and chemoresistant breast cancer. Biochim Biophys Acta 1785: 96-132, 2008

11. Orr GA, Verdier-Pinard P, McDaid H and Horwitz SB: Mechanisms of Taxol resistance related to microtubules. Oncogene 22: 7280-7295, 2003.

12. Berrieman HK, Lind MJ and Cawkwell L: Do beta-tubulin mutations have a role in resistance to chemotherapy? Lancet Oncol 5: 158-164, 2004

13. Kavallaris M, Tait AS, Walsh BJ, et al: Multiple microtubule alterations are associated with Vinca alkaloid resistance in human leukemia cells. Cancer Res 61: 5803-5809, 2001.

14. Hari M, Loganzo F, Annable T, et al: Paclitaxel-resistant cells have a mutation in the paclitaxel-binding region of beta-tubulin (Asp26Glu) and less stable microtubules. Mol Cancer Ther 5: 270-278, 2006

15. Yang $\mathrm{H}$ and Cabral F: Heightened sensitivity to paclitaxel in Class IVa beta-tubulin-transfected cells is lost as expression increases. J Biol Chem 282: 27058-27066, 2007.
16. Aoki D, Oda Y, Hattori S, et al: Overexpression of class III betatubulin predicts good response to taxane-based chemotherapy in ovarian clear cell adenocarcinoma. Clin Cancer Res 15: 1473-1480, 2009

17. Livak KJ and Schmittgen TD: Analysis of relative gene expression data using real-time quantitative PCR and the 2(-Delta Delta $\mathrm{C}(\mathrm{T})$ ) method. Methods 25: 402-408, 2001.

18. Sumizawa T, Chen ZS, Chuman Y, et al: Reversal of multidrug resistance-associated protein-mediated drug resistance by the pyridine analog PAK-104P. Mol Pharmacol 51: 399-405, 1997.

19. Shi Z, Tiwari AK, Shukla S, et al: Inhibiting the function of $\mathrm{ABCB} 1$ and $\mathrm{ABCG} 2$ by the EGFR tyrosine kinase inhibitor AG1478. Biochem Pharmacol 77: 781-793, 2009.

20. Minotti AM, Barlow SB and Cabral F: Resistance to antimitotic drugs in Chinese hamster ovary cells correlates with changes in the level of polymerized tubulin. J Biol Chem 266: 3987-3994, 1991.

21. Westermann S and Weber K: Post-translational modifications regulate microtubule function. Nat Rev Mol Cell Biol 4: 938-947, 2003.

22. Sasse R and Gull K: Tubulin post-translational modifications and the construction of microtubular organelles in Trypanosoma brucei. J Cell Sci 90: 577-589, 1988.

23. Belhoussine R, Morjani H, Sharonov S, Ploton D and Manfait M: Characterization of intracellular $\mathrm{pH}$ gradients in human multidrug-resistant tumor cells by means of scanning microspectrofluorometry and dual-emission-ratio probes. Int J Cancer 81: 81-89, 1999.

24. Jiang LW, Maher VM, McCormick JJ and Schindler M: Alkalinization of the lysosomes is correlated with ras transformation of murine and human fibroblasts. J Biol Chem 265: 4775-4777, 1990.

25. Altan N, Chen Y, Schindler M and Simon SM: Defective acidification in human breast tumor cells and implications for chemotherapy. J Exp Med 187: 1583-1598, 1998.

26. Gong Y, Duvvuri M and Krise JP: Separate roles for the Golgi apparatus and lysosomes in the sequestration of drugs in the multidrug-resistant human leukemic cell line HL-60. J Biol Chem 278: 50234-50239, 2003

27. Kokkonen N, Rivinoja A, Kauppila A, Suokas M, Kellokumpu I and Kellokumpu S: Defective acidification of intracellular organelles results in aberrant secretion of cathepsin D in cancer cells. J Biol Chem 279: 39982-39988, 2004.

28. Alvarez M, Paull K, Monks A, et al: Generation of a drug resistance profile by quantitation of $\mathrm{mdr}-1 / \mathrm{P}$-glycoprotein in the cell lines of the National Cancer Institute Anticancer Drug Screen. J Clin Invest 95: 2205-2214, 1995. 